\title{
Fertility preservation education for pediatric hematology-oncology fellows, faculty and advanced practice providers: A pilot study
}

\author{
Kristiyana Kaneva ${ }^{1}$, Laura Erickson ${ }^{1}$, Erin Rowell ${ }^{1}$, and Sherif Badawy ${ }^{2}$ \\ ${ }^{1}$ Ann and Robert H Lurie Children's Hospital of Chicago \\ ${ }^{2}$ Northwestern University Feinberg School of Medicine
}

September 16, 2020

\begin{abstract}
Infertility secondary to chemotherapy and/or myeloablative conditioning regimens prior to stem cell transplantation is an important cause of morbidity and psychosocial distress among pediatric cancer patients. Known options exist for fertility preservation; however, knowledge among providers varies. We conducted a pilot study with an educational intervention over one-hour for hematology-oncology faculty, fellows, and advanced practice providers. Participants completed pre-/post-test assessment on fertility preservation knowledge. Participants' pre-test mean (SD) score was 53\% (17\%), which significantly increased to $72 \%(11 \%)$ in the post-test $(\mathrm{P}=0.0004)$. We demonstrated that a fertility education intervention could improve knowledge regarding infertility risk assessment and fertility preservation options.
\end{abstract}

\section{Main Text}

\section{Introduction}

Infertility secondary to chemotherapy, radiation therapy, and/or myeloablative conditioning regimen prior to hematopoietic stem cell transplantation (HSCT) is an important cause of morbidity and psychosocial distress among pediatric cancer patients [1]. Although there are several options for fertility preservation, they are often overlooked and deemed less important than other therapy related late effects [2]. Infertility is one of the primary concerns of cancer survivors who report symptoms of post-traumatic stress disorder (PTSD) related to infertility as long as 10 years post therapy [3]. Therefore, it is essential for the treating providers to discuss infertility risk and fertility preservation options with all female and male patients undergoing gonadotoxic therapy, and their families, before treatment starts [4].

Alkylating chemotherapy agents, such as cyclophosphamide, present the greatest risk of infertility as determined by the cyclophosphamide equivalent dose (CED). Additionally, dose dependent radiation therapy to the ovaries or testes, gonadectomy and myeloablative conditioning regimens (e.g., Busulfan) for HSCT present another significant fertility risk [5]. Meacham et al recently developed a standardized risk assessment for gonadal insufficiency and infertility secondary to treatment in children, adolescents, and young adults with cancer compared to the general population [5].

Fertility preservation options for males include sperm banking, testicular sperm extraction (TESE) and testicular tissue cryopreservation (TTC). Sperm banking is only available for post-pubertal males and must be completed before any therapy is started, otherwise the semen is only to be used as last resort due to potential effects on DNA[6]. TESE is an option for post-pubertal males who cannot produce a semen sample[6], and TTC is the only option available for pre-pubertal males undergoing gonadotoxic therapy, and it is still considered experimental at this time [7]. 
Fertility preservation options for females include oocyte and embryo cryopreservation, ovarian tissue cryopreservation (OTC) and ovarian transposition for those undergoing pelvic radiation therapy [8]. Oocyte and embryo cryopreservation are only available for post-pubertal females, and embryo cryopreservation requires the availability of sperm, which is not feasible for many teenagers and young adults. OTC is the only option available for pre-pubertal females undergoing gonadotoxic therapy, and based on recent American Society of Reproductive Medicine (ASRM) practice committee opinion, it is no longer considered experimental [9]. Additionally, the 2019 ASRM guidelines include general recommendations on fertility preservation options for patients undergoing gonadotoxic therapy[9],

\section{Methods}

This pilot pre-post medical education interventional study focused on provider knowledge of infertility risk and fertility preservation options related to treatment for cancer and hematologic conditions. Participants included pediatric hematology-oncology faculty, fellows and advance practice providers (APPs) at Lurie Children's Hospital of Chicago.

The study intervention consisted of a one-hour educational session during time that is typically reserved for the weekly divisional case conference. Due to COVID-19 pandemic restrictions, the educational session was led and delivered virtually via Zoom. Participants were allowed to ask questions during and after the session. The educational materials covered information on: (1) different gonadotoxic therapies, including specific dosing thresholds that place patients at a significant risk of infertility from alkylating chemotherapy, heavy metals, radiation therapy, surgery and HSCT conditioning regimens; (2) different methods for fertility preservation making a clear distinction between methods available for pre-pubertal and post-pubertal patients; (3) general procedures and biology behind TTC and OTC including future directions geared toward in vitro maturation of sperm and oocytes; and finally (4) the role of the primary team in facilitating a fertility preservation discussion at diagnosis as well as the appropriate timing and process for consulting the fertility preservation team. Key educational points from the session are summarized in Table 1 . These points are based on the 2020 Meacham et al risk assessment study and the 2019 ASRM fertility preservation guidelines[5, 9].

We conducted pre- and post-tests (Supplemental File 1) in order to assess participants' knowledge on infertility risk and fertility preservation options before and after our study intervention, respectively. Both tests included the same 10 multiple choice questions. Participants received the pre and post-tests via email two weeks prior and immediately after the planned educational session, respectively. The study was approved by the Institutional review board (IRB).

\section{Results}

A total of 40 faculty, fellows and advance practice providers participated in the study. Participants' pre-test mean (SD) score of correct answers was 53\% (17\%) with a median (range) of 55\% (0\%-90\%). Participants' post-test mean (SD) score significantly increased to $72 \%(11 \%)$ with a median (range) of $70 \%$ (50\%-90\%), $P$ $=0.0004$ (Figure 1). All participants who completed the post-test had also completed the pre-test and attended the virtual educational session.

\section{Discussion}

In this pilot pre-post medical education interventional study, we demonstrated a significant improvement in participants' knowledge on topics related to infertility risk and fertility preservation options among pediatric hematology and oncology providers. Participants' interactivity was likely slightly limited by the virtual nature of this education session, and in- person session may have led to a more dynamic discussion. However, even in a virtual format, we believe that this one-hour educational intervention session has increased awareness regarding the importance of discussing infertility risk and fertility preservation options with all our patients and their families.

Prior studies have emphasized the need for increased education on treatment- related infertility risk and fertility preservation options for pediatric oncology patients [10,11]. Overbeek et al conducted a nationwide 
cross-sectional study where a survey was sent to 64 registered pediatric oncologists in the Netherlands. Of the 37 oncologists who participated, $<25 \%$ reported a moderate or high confidence in their knowledge on fertility preservation techniques [12]. Further, Murphy et al developed a fertility preservation brochure that was evaluated by patients, parents and healthcare providers, and later optimized based on this feedback [13]. In support, Kemertzis et al conducted a survey-based longitudinal study of clinicians involved in fertility preservation discussions which included baseline assessment as well as a follow-up survey administered after each toolkit use. The fertility preservation toolkit resulted in significant perceived and actual benefits [14]. Similarly, Takeuchi et al conducted a 4-hour educational program for non-physician health care providers focused on risk of cancer treatment, fertility preservation, and psychosocial support. The study reported significant improvement in in confidence and knowledge among participants, but not in counseling skills [15]. This lack of improvement of counseling skills emphasizes the importance of having a dedicated fertility preservation team in the pediatric hematology-oncology department that can provide adequate counseling for the patients and their families. Moreover, a recent publication involved conducting a cross-sectional survey of information and resources related to fertility preservation on websites from top ranked pediatric cancer programs[16]. The authors showed that a fertility team was referenced on the website of $36 \%$ of programs and only $32 \%$ provided fertility preservation educational resources for patients. In addition, information was particularly limited for prepubertal males and Spanish-speaking patients. This study emphasizes the need for continued fertility preservation education and resources.

In conclusion, our one-hour educational intervention session led to statistically significant improvement in participants' knowledge on topics related to infertility risk and fertility preservation among pediatric hematology and oncology providers. We plan to continue this study on an annual basis and include more participants over time with pre-/post assessments and educational session intervention being completed in one setting to optimize participation.

Table 1 . Key educational points related to significantly increased risk of infertility adapted from Meacham et al [5] and fertility preservation options for pre and post pubertal patients based on the 2019 ASRM guidelines[9]. CED: cyclophosphamide equivalent dosing.

\begin{tabular}{|c|c|c|}
\hline $\begin{array}{l}\text { Significantly Increased Risk } \\
\text { of Infertility }\end{array}$ & $\begin{array}{l}\text { Significantly Increased Risk } \\
\text { of Infertility }\end{array}$ & $\begin{array}{l}\text { Significantly Increased Risk } \\
\text { of Infertility }\end{array}$ \\
\hline & Male & Female \\
\hline Alkylators CED $\left(\mathrm{gm} / \mathrm{m}^{2}\right)$ & [?] 4 & Prepubertal: $>12$ Pubertal: $>8$ \\
\hline $\begin{array}{l}\text { Heavy Metals mg/m² } \\
\text { (Cisplatin/Carboplatin) }\end{array}$ & $\begin{array}{l}\text { Cisplatin > } 500 \text { is significantly } \\
\text { increased risk }\end{array}$ & Minimally increased risk \\
\hline Hematopoietic Stem Cell & Alkylator +/-Total body & Alkylator $+/$-Total body \\
\hline Transplant & $\begin{array}{l}\text { irradiation Myeloablative and } \\
\text { Reduced intensity regimens }\end{array}$ & $\begin{array}{l}\text { irradiation Myeloablative and } \\
\text { Reduced intensity regimens }\end{array}$ \\
\hline Radiation Exposure & $\begin{array}{l}\text { Testicular [?] } 4.0 \text { Gy } \\
\text { Hypothalamus }>40 \text { Gy }\end{array}$ & $\begin{array}{l}\text { Ovarian: [?] } 15 \text { Gy (Prepubertal) } \\
\text { [?] } 10 \text { Gy (Pubertal) } \\
\text { Hypothalamus }>40 \text { Gy }\end{array}$ \\
\hline Surgery & $\begin{array}{l}\text { Orchiectomy (bilateral) } \\
\text { Retroperitoneal lymph node } \\
\text { dissection (RPLND) }\end{array}$ & Oophorectomy (bilateral) \\
\hline Fertility Preservation & Fertility Preservation & Fertility Preservation \\
\hline Options & $\begin{array}{l}\text { Options } \\
\text { Male }\end{array}$ & $\begin{array}{l}\text { Options } \\
\text { Female }\end{array}$ \\
\hline Post-Pubertal & $\begin{array}{l}\text { Sperm banking: prior *any* } \\
\text { chemotherapy }\end{array}$ & Embryo cryopreservation \\
\hline & $\begin{array}{l}\text { Testicular sperm extraction } \\
\text { (TESE) }\end{array}$ & Oocyte cryopreservation \\
\hline
\end{tabular}




\begin{tabular}{lll}
\hline $\begin{array}{l}\text { Significantly Increased Risk } \\
\text { of Infertility }\end{array}$ & $\begin{array}{l}\text { Significantly Increased Risk } \\
\text { of Infertility }\end{array}$ & $\begin{array}{l}\text { Significantly Increased Risk } \\
\text { of Infertility }\end{array}$ \\
\hline $\begin{array}{l}\text { Pre-Pubertal (or } \\
\text { Post-Pubertal) }\end{array}$ & $\begin{array}{l}\text { Testicular tissue } \\
\text { cryopreservation (TTC) - } \\
\text { experimental }\end{array}$ & $\begin{array}{l}\text { Ovarian tissue cryopreservation } \\
\text { (OTC) - no longer experimental }\end{array}$ \\
& & $\begin{array}{l}\text { Ovarian transposition in } \\
\text { patients receiving pelvic } \\
\text { radiation }\end{array}$ \\
GnRH agonists & $\begin{array}{l}\text { Can be offered to women with } \\
\text { breast cancer for protection } \\
\text { from ovarian insufficiency but } \\
\text { should Not replace oocyte or } \\
\text { embryo cryopreservation }\end{array}$ \\
\hline
\end{tabular}

Figure 1. Box plot comparison of pre and post fertility education test scores . Scores were reported in percent correctly answered questions. Median scores are depicted as a horizontal line (55 pretest, 70 post-test). Mean is depicted as an " $\mathrm{x}$ " (53 pre-test, 72 post-test). Outlier points are depicted as distinct colored circles $(0,20,80,90 \%$ for pre-test and $50 \%$ for post-test).

\section{References}

1. Barton, S.E., et al., Infertility, infertility treatment, and achievement of pregnancy in female survivors of childhood cancer: a report from the Childhood Cancer Survivor Study cohort. Lancet Oncol, 2013. 14 (9): p. $873-81$.

2. Hohmann, C., et al., Patient counselling on the risk of infertility and its impact on childhood cancer survivors: results from a national survey. J Psychosoc Oncol, 2011. 29 (3): p. 274-85.

3. Schover, L.R., Patient attitudes toward fertility preservation. Pediatr Blood Cancer, 2009. 53 (2): p. 281-4.

4. Oktay, K., et al., Fertility Preservation in Patients With Cancer: ASCO Clinical Practice Guideline Update. J Clin Oncol, 2018.36 (19): p. 1994-2001.

5. Meacham, L.R., et al., Standardizing Risk Assessment for Treatment-Related Gonadal Insufficiency and Infertility in Childhood Adolescent and Young Adult Cancer: The Pediatric Initiative Network Risk Stratification System. J Adolesc Young Adult Oncol, 2020.

6. Yu, R.N., Fertility preservation in the pediatric cancer patient. Curr Opin Urol, 2019. 29 (5): p. 477-480.

7. Valli-Pulaski, H., et al., Testicular tissue cryopreservation: 8 years of experience from a coordinated network of academic centers.Hum Reprod, 2019. 34 (6): p. 966-977.

8. Druckenmiller, S., et al., Successful Oocyte Cryopreservation in Reproductive-Aged Cancer Survivors. Obstet Gynecol, 2016.127 (3): p. 474-80.

9. Practice Committee of the American Society for Reproductive Medicine. Electronic address, a.a.o., Fertility preservation in patients undergoing gonadotoxic therapy or gonadectomy: a committee opinion.Fertil Steril, 2019. 112 (6): p. 1022-1033.

10. Ginsberg, J.P., Educational paper: the effect of cancer therapy on fertility, the assessment of fertility and fertility preservation options for pediatric patients. Eur J Pediatr, 2011.170 (6): p. 703-8.

11. Norga, K.K., Pediatric oncology for the general pediatrician: introduction to the Educational series. Eur J Pediatr, 2011.170 (2): p. 253-5. 
12. Overbeek, A., et al., Practice, attitude and knowledge of Dutch paediatric oncologists regarding female fertility. Neth J Med, 2014. 72 (5): p. 264-70.

13. Murphy, D., K.K. Sawczyn, and G.P. Quinn, Using a patient-centered approach to develop a fertility preservation brochure for pediatric oncology patients: a pilot study. J Pediatr Adolesc Gynecol, 2012. 25 (2): p. 114-121.

14. Kemertzis, M.A., et al., Fertility Preservation Toolkit: A Clinician Resource to Assist Clinical Discussion and Decision Making in Pediatric and Adolescent Oncology. J Pediatr Hematol Oncol, 2018.40 (3): p. e133e139.

15. Takeuchi, E., et al., The effects of an educational program for non-physician health care providers regarding fertility preservation. Support Care Cancer, 2018. 26 (10): p. 3447-3452.

16. Hoyos-Martinez, A., et al., Availability of Fertility Preservation Information on the Websites of U.S. News and World Report Top-Ranked Pediatric Cancer Programs. J Adolesc Young Adult Oncol, 2020.

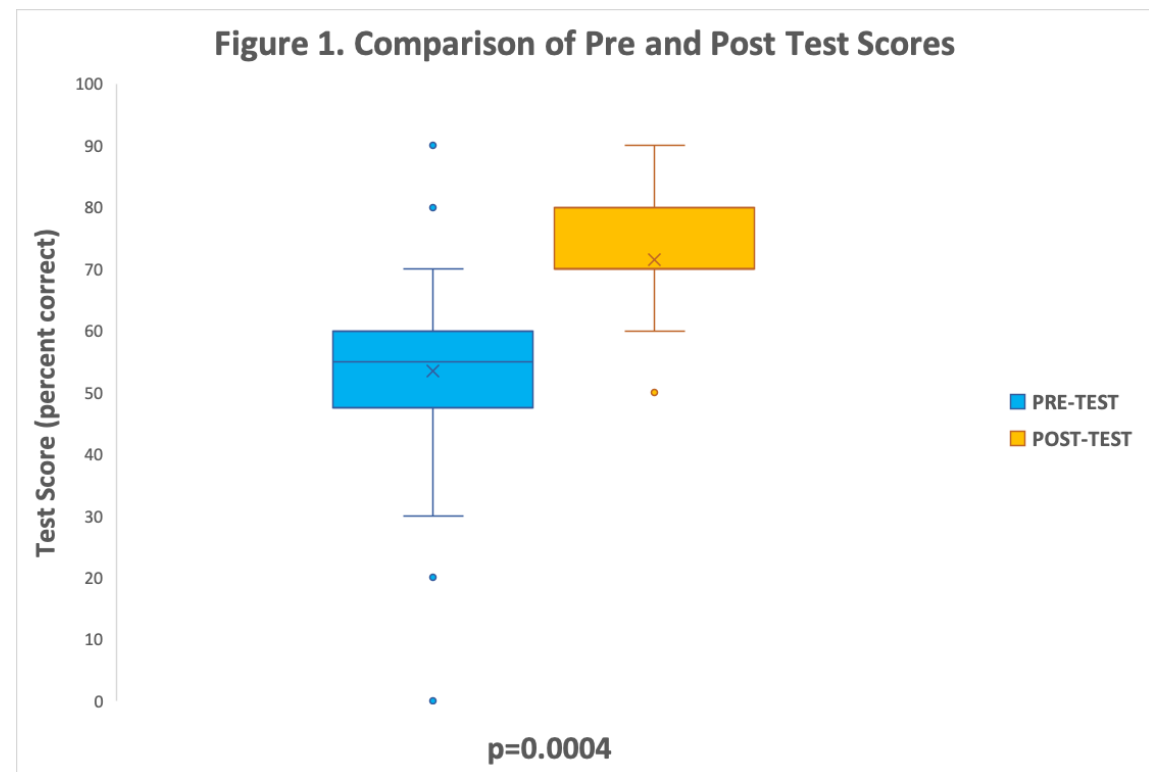




\begin{tabular}{|c|c|c|}
\hline \multicolumn{3}{|c|}{ Significantly Increased Risk of Infertility } \\
\hline & Male & Female \\
\hline $\begin{array}{c}\text { Alkylators } \\
\text { CED }\left(\mathrm{gm} / \mathrm{m}^{2}\right)\end{array}$ & $\geq 4$ & $\begin{array}{c}\text { Prepubertal: }>12 \\
\text { Pubertal: }>8\end{array}$ \\
\hline $\begin{array}{c}\text { Heavy Metals mg/m² } \\
\text { (Cisplatin/Carboplatin) }\end{array}$ & $\begin{array}{c}\text { Cisplatin }>500 \text { is } \\
\text { significantly increased risk }\end{array}$ & Minimally increased risk \\
\hline $\begin{array}{c}\text { Hematopoietic Stem Cell } \\
\text { Transplant }\end{array}$ & $\begin{array}{l}\text { Alkylator }+/ \text {-Total body } \\
\text { irradiation } \\
\text { Myeloablative and } \\
\text { Reduced intensity regimens }\end{array}$ & $\begin{array}{c}\text { Alkylator }+/ \text {-Total body } \\
\text { irradiation } \\
\text { Myeloablative and } \\
\text { Reduced intensity regimens }\end{array}$ \\
\hline Radiation Exposure & $\begin{array}{l}\text { Testicular } \geq 4.0 \mathrm{~Gy} \\
\text { Hypothalamus }>40 \mathrm{~Gy}\end{array}$ & $\begin{array}{c}\text { Ovarian: } \geq 15 \text { Gy } \\
\text { (Prepubertal) } \\
\geq 10 \text { Gy (Pubertal) } \\
\text { Hypothalamus }>40 \text { Gy }\end{array}$ \\
\hline Surgery & $\begin{array}{ll}\text { - } & \text { Orchiectomy } \\
\text { (bilateral) } \\
\text { - } & \text { Retroperitoneal lymph } \\
\text { node dissection } \\
\text { (RPLND) }\end{array}$ & Oophorectomy (bilateral) \\
\hline \multicolumn{3}{|c|}{ Fertility Preservation Options } \\
\hline & Male & Female \\
\hline \multirow[t]{2}{*}{ Post-Pubertal } & $\begin{array}{l}\text { Sperm banking: prior *any* } \\
\text { chemotherapy }\end{array}$ & Embryo cryopreservation \\
\hline & $\begin{array}{l}\text { Testicular sperm extraction } \\
\text { (TESE) }\end{array}$ & Oocyte cryopreservation \\
\hline \multirow[t]{2}{*}{$\begin{array}{c}\text { Pre-Pubertal (or Post- } \\
\text { Pubertal) }\end{array}$} & \multirow[t]{2}{*}{$\begin{array}{l}\text { Testicular tissue } \\
\text { cryopreservation (TTC) - } \\
\text { experimental }\end{array}$} & $\begin{array}{l}\text { Ovarian tissue } \\
\text { cryopreservation (OTC) - no } \\
\text { longer experimental }\end{array}$ \\
\hline & & $\begin{array}{l}\text { Ovarian transposition in } \\
\text { patients receiving pelvic } \\
\text { radiation }\end{array}$ \\
\hline GnRH agonists & $\begin{array}{l}\text { Not effective and Not } \\
\text { recommended }\end{array}$ & $\begin{array}{l}\text { Can be offered to women with } \\
\text { breast cancer for protection } \\
\text { from ovarian insufficiency but } \\
\text { should Not replace oocyte or } \\
\text { embryo cryopreservation }\end{array}$ \\
\hline
\end{tabular}

